\title{
Karakteristik Kawasan Wisata Kampung Laut Bontang Kuala Berbasis Ekowisata
}

\author{
Penulis Fonita Andastry dan Hertiari Idajati, ST, M.Sc \\ Jurusan Perencanaan Wilayah dan Kota, Fakultas Teknik Sipil dan Perencanaan, Institut Teknologi \\ Sepuluh Nopember (ITS) \\ Jl. Arief Rahman Hakim, Surabaya 60111 Indonesia \\ email: hertiari.idajati@urplan.its.ac.id
}

\begin{abstract}
Abstrak - Kota Bontang merupakan salah satu kota yang berada di Propinsi Kalimantan Timur. Kota Bontang sendiri terkenal akan potensi kekayaan industri migas dan kondensatnya. Namun disampingn itu, Kota Bontang memiliki potensi pariwisata yang dapat dikembangkan yaitu berupa kawasan wisata Kampung Laut Bontang Kuala untuk dijadikan objek wisata. Penelitian ini bertujuan untuk mengetahui karakteristik kawasan wisata Kampung Laut Bontang Kuala. Tahapan penelitian ini dimulai dengan mengidentifikasi komponen pariwisata di kawasan wisata Kampung Laut Bontang Kuala berbasis ekowisata menggunakan teknik analisa deskriptif kualitatif. Selanjutnya dilakukan observasi terkait variabel amatan yang ada di kawasan wisata Kampung Laut Bontang Kuala. Hasil identifikasi komponen pariwisata yang ada di kawasan wisata Kampung Laut Bontang Kuala dugunakan untuk merumuskan arahan pengembangan kawasan wisata Kampung Laut Bontang Kuala berbasis ekowisata. Hasil penelitian menunjukkan bahwa komponen pariwisata dan ekowisata pada kawasan wisata Kampung Laut Bontang Kuala sudah sesuai untuk dikembangkan menjadi kawasan ekowisata.
\end{abstract}

Kata Kunci-ekowisata, kampung laut bontang kuala, pengembangan pariwisata

\section{PENDAHULUAN}

$S^{\mathrm{E}}$ EKTOR pariwisata merupakan salah satu sektor pembangunan yang terus dipromosikan oleh pemerintah.

Hal ini disebabkan karena pariwisata mempunyai peran yang sangat penting dalam perekonomian wilayah setempat. Sektor pariwisata dapat dikategorikan kedalam kelompok industri terbesar dimana $8 \%$ ekspor barang dan jasa berasal dari sektor pariwisata [1]

Di Indonesia sendiri pariwisata memiliki posisi yang strategis dalam perkembangan perekonomian. Peran pariwisata semakin penting dengan semakin berkembangnya perdagangan dan investasi luar negeri. Oleh karenanya perlu adanya pengembangan destinasi dan pemasaran pariwisata di wilayah - wilayah yang ada di Indonesia guna meningkatkan devisa pada masing - masing wilayah di Indonesia (Yudhokusumo, 2013). Salah satunya propinsi Kalimantan Timur yang memiliki banyak potensi dan sumber daya alam yang belum dikembangkan secara maksimal.

Budaya dan pariwisata merupakan salah satu cara dalam menjaga lingkungan dan meningkatkan pendapatan masyarakat setempat [2]

Propinsi Kaliamantan Timur sendiri merupakan salah satu tujuan wisata yang memiliki potensi budaya dan pariwisata yang tidak kalah dengan wisata lainnya di Indonesia. Hampir 90\% objek wisata yang ada di Kalimantan Timur berupa wisata alam dan $10 \%$ lainnya merupakan objek wisata buatan untuk mendukung pariwisata di sana. Beberapa objek wisata di Propinsi Kalimantan Timur yang memiliki diantaranya objek wisata Balikapan, obejk wisata Bontang, objek wisata Tarakan, objek wisata Kutai Kartanegara, objek wisata Kutai Barat, objek wisata Kutai timur dan objek wisata Paser [3]

Menurut Dinas Kebudayaan dan Pariwisata Kota Bontang (Disbudpar Kota Bontang (2012:9)), potensi dan daya tarik wisata Kota Bontang di antaranya adalah Pulau Beras Basah, Pulau Segajah, Pulau Gusung, Hutan Mangrove, Taman Nasional Kutai, Perkampungan Laut Bontang Kuala, Pulau Selangan, Pulau Tihik-tihik, Pulau Melahing, Pulau Selambai, Perkampungan Guntung, Danau Kanaan dan Makam Toraja, Kawasan Berbas Pantai, Hutan Kota, Kawasan wisata Cafe Singapura, Taman Cibodas, Hutan Kota Wanatirta, Pantai Marina Badak, Kawasan Industri PKT dan Kawasan Industri PT Badak. Masing - masing kawasan wisata memiliki ciri khas tersendiri. Sebagian besar potensi dan daya tarik yang ditawarkan di Kota Bontang merupakan wisata alam, seperti Pulau Bersa Basah. Namum disamping itu terdapat salah satu kawasan wisata yang menawarkan wisata budaya yaitu kawasan wisata Kampung Laut Bontang Kuala. Hal ini juga sesuai dengan arahan yang ada dalam dokumen rencana tata ruang wilayah Kota Bontang [4]

Kawasan wisata Kampung Laut Bontang Kuala terletak di wilayah timur Kota Bontang berada di daerah pesisir barat perairan Selat Makasar. Dengan jumlah penduduk 4.823 jiwa (Sumber: Profil Kelurahan Bontang Kuala, 2014) dengan luas wilayah sebesar $585 \mathrm{Ha}$ dan luas areal terbangun sebesar $64 \mathrm{Ha}$. Kawasan wisata Kampung Laut Bontang Kuala ini merupakan salah satu tujuan wisata lokal maupun mancanegara. Kawasan wisata ini merupakan perkampungan yang awalnya dihuni oleh nelayan. Kawasan Kampung Laut Bontang Kuala ini juga merupakan kawasan konservasi mangrove [5]

Kawasan wisata Kampung Laut Bontang Kuala dari segi pemenuhan infrastruktur sudah cukup memadai dan cukup tertata. Jumlah pengunjungnya pun setiap tahun masih cukup banyak. Pada tahun 2015 saja total pengunjung kawasan wisata Kampung Laut Bontang Kuala dalam setahun sebanyak 2.377 pengunjung (Sumber: Dinas Pariwisata Kota Bontang, 2015). Hanya saja belum ada program atau arahan yang jelas terkait 
dengan pengembangan kawasan wisata ini, padahal nilai jual kawasan ini cukup baik [6]

Pada kawasan wisata Kampung Laut Bontang Kuala terdapat dua kegiatan penting dimana ada aktivitas manusia yang berada di atas perkampungan laut dan juga disisi lainnya terdapat kawasan konservasi mangrove. Namun dalam pengembangan kawasan Kampung Laut Bontang Kuala ini tidak cukup hanya mempertahankan hutan mangrove karena tidak menguntungkan secara langsung bagi penduduk setempat, pemerintah maupun investor. Tetapi bagaimana mengakomodasi kepentingan konservasi dengan kepentingan penduduk, pemerintah maupun investor. Pengembangan yang sesuai untuk kawasan Kampung Laut Bontang Kuala adalah pengembangan ekowisata [7]

Menurut Departemen Pariwisata Republik Indonesia, Ekowisata merupakan konsep pengembangan pariwisata berkelanjutan yang bertujuan untuk mendukung upaya-upaya pelestarian lingkungan (alam dan budaya) dan meningkatkan partisipasi masyarakat dalam pengelolaan, sehingga memberikan manfaat ekonomi kepada masyarakat dan pemerintah setempat. Ekowisata dapat mendukung kegiatan konservasi alam yang ada di kawasan Kampung Laut Bontang Kuala sesuai dengan potensi dan daya dukung wilayah. Ekowisata dapat dikatakan sebagai kegiatan pariwisata yang berwawasan lingkungan dengan menitikberatkan pada kegiatan konservasi alam, aspek pendidikan dan pemperdayaann masyarakat lokal bidang sosial, budaya dan ekonomi [8]

Namun demikian belum ada arahan pengembangan untuk pengembangan kawasan wisata Kampung Laut Bontang Kuala sebagai kawasan ekowisata. Oleh karena itu perlu adanya penelitian untuk mencari arahan pengembangan kawasan wisata Kampung Laut Bontang Kuala sebagai kawasan ekowisata.

\section{METODE PENELITIAN}

\section{A. Jenis dan Pendekatan Penelitian}

Pendekatan yang digunakan dalam penelitian ini adalah pendekatan rasionalistik. [9] Jenis penelitian dalam penelitian ini adalah deskriptif kuantitatif.

\section{B. Variabel Penelitian}

Variabel penelitian merupakan turunan dari faktor yang bersifat kuantitatif maupun kualitatif. Berdasarkan tinjauan pustaka yang telah didapatkan beberapa variabel penelitian terkait pengembangan kawasan wisata Kampung Laut Bontang Kuala berbasis ekowisata. Variabel tersebut merupakan variabel yang mempengaruhi pengembangan kawasan wisata Kampung Laut Bontang Kuala. Berikut ini tabel variabel pada penelitian ini :

Tabel 1 Variabel Penelitian

\begin{tabular}{lll}
\hline \hline Aspek Penelitian & \multicolumn{1}{c}{ Indikator } & \multicolumn{1}{c}{ Variabel } \\
\hline Komponen & Daya Tarik Wisata & Sumber Daya Alam \\
Pariwisata & & Sumber Daya Budaya \\
& & Jalan \\
& Aksesibilitas & Angkutan \\
& Fasilitas Wisata & Restoran \\
& & Penginapan/Hotel
\end{tabular}

\begin{tabular}{lll}
\hline \hline Aspek Penelitian & \multicolumn{1}{c}{ Indikator } & \multicolumn{1}{c}{ Variabel } \\
\hline & & Pusat Informasi \\
& Toko Souvenir \\
& Fasilitas Pendukung & Fasilitas Peribadatan \\
& & Fasilitas Kesehatan \\
& Fasilitas Keamanan \\
& Prasarana & Listrik \\
& & Air Bersih \\
& Persampahan \\
\hline \hline
\end{tabular}

Sumber : Sintesa Tinjauan Pustaka, 2016

\section{Metode Analisis}

Analisis yang digunakan dalam menganalisis komponen pariwisata yang ada di kawasan wisata Kampung Laut Bontang Kuala adalah analisis deskriptif kualitatif.

Metode pengumpulan data dalam penelitian ini terbagi menjadi dua primer dan sekunder. Primer melalui observasi di wilayah penelitian, melihat bagaimana kondisi eksisting dari komponen pariwisata yang ada di kawasan wisata Kampung Laut Bontang Kuala. Sedangkan sekunder dilihat dari komponen pariwisata yang didapatkan dari hasil sintesa kajian pustaka terkait dengan komponen pariwisata. Dari hasil observasi tersebut akan diketahui bagaimana karakteristik pariwisata yang ada di kawasan Kampung Laut Bontang Kuala.

\section{HASIL DAN PEMBAHASAN}

\section{A. Identifikasi Komponen Pariwisata dan Ekowisata di Kawasan Wisata Kampung Laut Bontang Kuala}

Analisis yang digunakan untuk mengeksplorasi dan mengidentifikasi komponen pariwisata di kawasan Kampung Laut Bontang Kuala berbasis ekowisata adalah analisis deksriptif kualitatif dimana akan ditampilkan fakta, keadaan dan fenomena yang terjadi ketika penelitian berlangsung dan menyajikan apa adanya. Sesuai dengan tahapan-tahapan apa saja yang harus dipenuhi. Tahapan pertama yakni membuat daftar variabel amatan. Daftar amatan ini dibuat berdasarkan dari hasil sintesa kajian pustaka dari berbagai teori yang ada terkait dengan komponen pariwisata maupun komponen ekowisata. Selanjutnya dilakukan observasi atau pengamatan langsung di wilayah penelitian. dari pengematan/observasi tersebut dapat diketahui dan disimpulkan bagaimana karakteristik pariwisata yang ada di kawasan wisata Kampung Laut Bontang Kuala dilihat dari kelengkapan komponen pariwisata dan ekowisata yang ada.

Berikut ini hasil observasi yang telah dilakukan dalam mengidentifikasi karakteristik pariwisata di kawasan wisata Kampung Laut Bontang Kuala:

1) Sumber Daya Alam

Berdasarkan hasil pengamatan di wilayah penelitian diketahui bahwa kawasan wisata Kampung Laut Bontang Kuala merupakan kawasa wisata bahari yang menawarkan keindahan perkampungan diatas laut dan juga pemandangan alam laut itu sendiri. Selain itu juga terdapat kawasan konservasi mangrove berada di sepanjang jalan menuju kawasan perkampungan diatas laut tersebut.

2) Sumber Daya Budaya 
Berdasarkan hasil pengamatan di wilayah penelitian diketahui bahwa sumber daya budaya yang ada di kawasan wisata ini berupa perayaan pesta laut tiap akhir tahun. Pesta laut ini merupakan pesta adat yang dilakukan sebagai bentuk rasa syukur terhadap Sang Pencipta atas hasil laut yang didapatkan para nelayan. Pesta laut ini juga merupakan adat atau tradisi yang masih terus dijalankan hingga saat ini sebagai upaya melestarikan warisan budaya Indonesia.

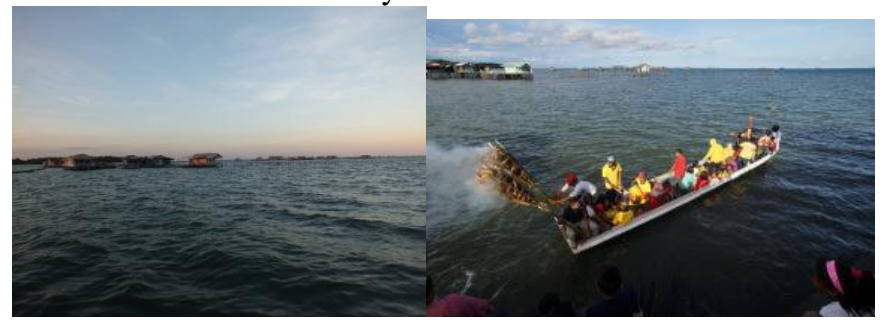

Gambar 1 Potret alam dan festival budata yang ada di kawasan wisata Kampung Laut Bontang Kuala

Sumber : Survey Primer, 2016

3) Sarana dan Prasarana

Sarana dan prasarana menjadi komponen yang penting dalam sebuah kawasan wisata. Sarana prasarana ini berupa jalan, trayek angkutan umum, listrik, air bersih dan persampahan.

a. Jalan dan Trayek Angkutan Umum

Pada kawasan wisata Kampung Laut Bontang Kuala berdasarkan hasil pengamatan diketahui bahwa akses jalan menuju kawasan wisata ini hanya ada satu jalan utama saja. Kondisi jalannya pun masih bagus dan terawat. Selanjutnya untuk mengelilingi kawasan perkampungan diatas laut pengunjung dapat menggunakan motor atau berjalan kaki melewati jalan-jalan yang terbuat dari kayu ulin, namun belum ada trayek angkutan umum yang menuju kawasan wisata ini. Kebanyakan para pengunjung menggunakan kendaraan pribadi mereka masing-masing untuk menuju kawasan wisata ini.

b. Prasarana Listrik

Pada kawasan wisata Kampung Laut Bontang Kuala berdasarkan hasil pengamatan diketahui bahwa prasarana listrik sudah tersedia dengan baik di kawasan wisata ini. Pasokan litrik didapatkan dari PLN setempat.

c. Prasarana Air Bersih

Pada kawasan wisata Kampung Laut Bontang Kuala berdasarkan hasil pengamatan diketahui bahwa penyediaan air bersih di kawasan wisata ini sudah baik. Kawasan wisata ini mendapat pasokan air bersih dai PDAM. Jadi untuk kebutuhan air bersih dapat terpenuhi dengan baik.

d. Prasarana Persampahan

Pada kawasan wisata Kampung Laut Bontang Kuala hasil pengamatan diketahui bahwa pada masing - masing rumah maupun tempat lain di kawasan wisata ini sudh tersedia bak sampah. Dimana nantinya akan ada petugas kebersihan yang mengambil sampah - sampah tersebut untuk nantinya dibuang ke TPS terdekat.

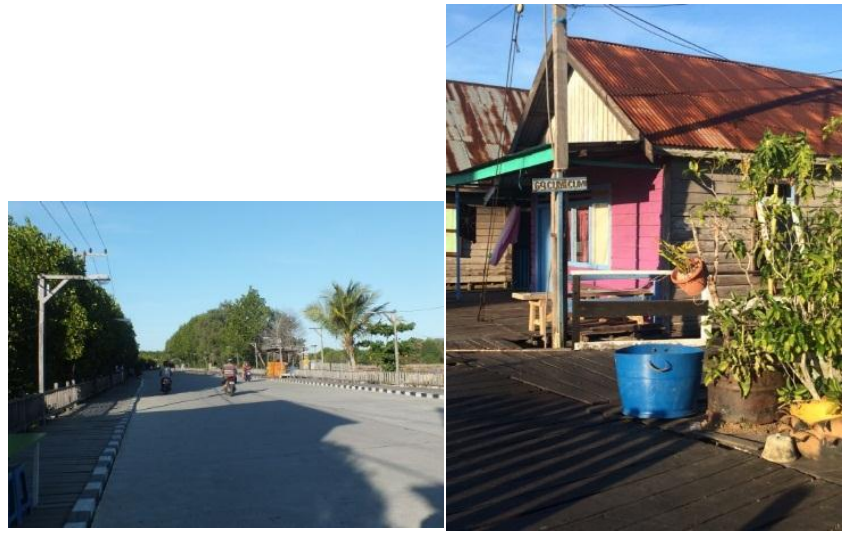

Gambar 2 Kondisi jalan dan sarana persampahan yang ada di kawasan Wisata Kampung Laut Bontang Kuala

Sumber : Survey Primer, 2016

\section{4) Akomodasi}

Akomodasi merupakan salah satu komponen penting yang harus ada pada kawasan wisata seperti 1)restoran, 2)hotel/penginapan, 3)pusat informasi dan 4)toko souvenir. Berikut ini penjelasannya :

a. Restoran

Pada kawasan wisata Kampung Laut Bontang Kuala berdasarkan hasil pengamatan diketahui bahwa terdapat restoran maupun deretan penjual makanan yang berada diujung kawasan perkmpungan ini. Terdapat restoran besar maupun sentra kuliner lainnya yang tidak begitu besar yang berada di kawasan sentra kuliner. Kebanyakan restoran dan sentra kuliner ini menjual makanan khas Kota Bontang yakni bawis gammi dan olahan laut lainnya.

b. Hotel/penginapan

Pada kawasan wisata Kampung Laut Bontang Kuala berdasarkan hasil pengamatan diketahui bahwa terdapat satu penginapan yang berada di sekitar kawasan ini. Hanya saja sekarang penginapan ini sudah tidak lagi difungsikan sebagai penginapan oleh pemiliknya.

c. Pusat Informasi

Pada kawasan wisata Kampung Laut Bontang Kuala berdasarkan hasil pengamatan diketahui bahwa saat ini sudah ada pusat informasi yang ada di kawasan wisata Kampung Laut Bontang Kuala ini yang dibangun tahun 2015. Bangunan pusat informasi ini merupakan bantuan dari PT. Badak LNG sebagai bagian dari Community Development PT. Badak LNG.

d. Toko Souvenir

Pada kawasan wisata Kampung Laut Bontang Kuala berdasarkan hasil pengamatan diketahui bahwa toko souvenir atau oleh-oleh yang ada di kawasan wisata ini hanya satu dan itu pun kecil dan kurang menarik jika dilihat dari luar.

5) Fasilitas Pendukung

Fasilitas pendukung menjadi salah satu komponen utama dalam kawasan wisata. Hal ini diperlukan guna memberikan kemudahan dan kenyamanan kepada wisatawan yang sedang berkunjung. Pada kawasan wisata Kampung Laut Bontang Kuala terdapat beberapa fasilitas pendukung yang ada diantaranya :

a. Fasilitas Peribadatan

Pada kawasan wisata Kampung Laut Bontang Kuala berdasarkan hasil pengamatan diketahui terdapat satu bangunan 
masjid yang merupakan masjid tertua yang ada di Kota Bontang. Selain bisa beribadah di masjid ini, pengunjung juga bisa melihat keindahan bangunan masjid ini yang terbuat dari kayu ulin dan sejarah dibalik masjid ini.

b. Fasilitas Kesehatan

Pada kawasan wisata Kampung Laut Bontang Kuala berdasarkan hasil pengamatan diketahui terdapat satu puskesmas pembantu yang ada di kawasan wisata ini yakni puskesmas pembantu yang ada di kampung laut ini. Kondisinya juga masih bagus dan cukup terawat.

c. Fasilitas Keamanan

Pada kawasan wisata Kampung Laut Bontang berdasarkan hasil pengamatan di wilayah penelitian diketahui bahwa kawasan wisata ini dekat dengan fasilitas keamanan seperti pemadam kebakaran. Namun beberapa kendaraan pemadam kebarakan ada yang kondisinya sudah tidak baik, seperti sudah tua dan berkarat.

Berikut ini dokumentasi hasil observasi di wilayah penelitian :

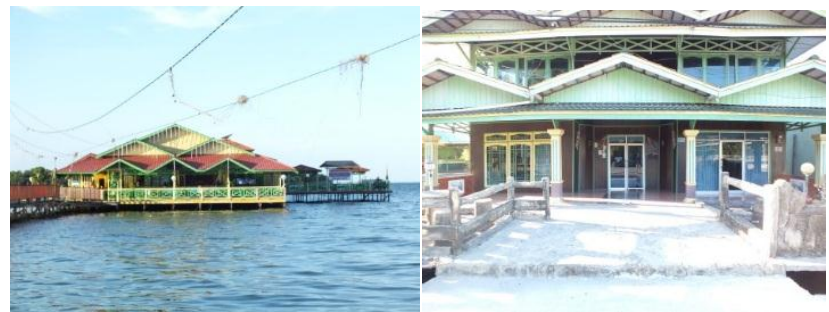

Gambar 3 Fasilitas restoran dan hotel yang ada di kawasan wisata Kampung Laut Bontang Kuala

Sumber : Survey Primer, 2016

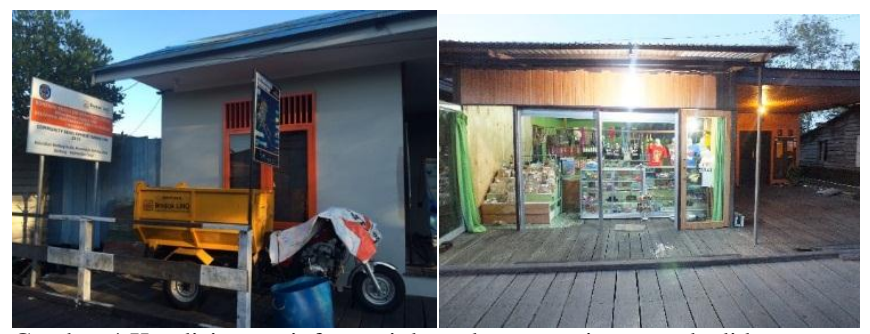

Gambar 4 Kondisi pusat informasi dan toko souvenir yang ada di kawasan wisata Kampung Laut Bontang Kuala

Sumber : Survey Primer, 2016

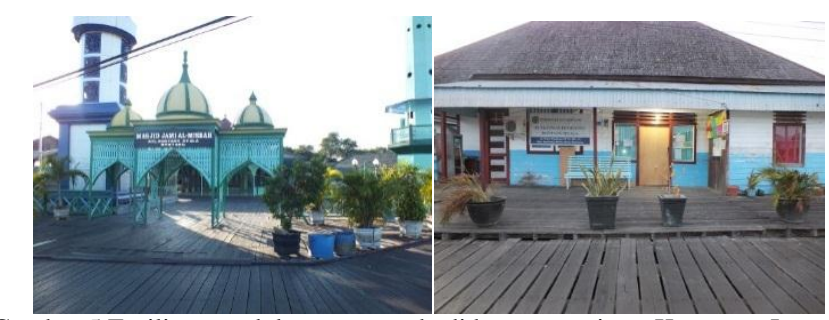

Gambar 5 Fasilitas pendukung yang ada di kawasan wisata Kampung Laut Bontang Kuala

Sumber : Survey Primer, 2016

\section{6) Lingkungan Alamiah}

Pada kawasan wisata Kampung Laut Bontang berdasarkan berdasarkan hasil pengamatan diketahui bahwa kawasan wisata Kampung Laut Bontang Kuala merupakan kawasan wisata alam yang menawarkan wisata laut, kawasan konservasi mangrove dan juga aktivitas masyarakat yang bermukim di kampung laut itu sendiri. Kawasan ini memberikan pengalaman kepada pengunjung bagaimana manusia dan lingkungan dapat hidup berdampingan.

\section{7) Konservasi}

Pada kawasan wisata Kampung Laut Bontang Kuala terdapat kawasan konservasi mangrove yang merupakan bagian dari Taman Nasional Kutai. Selain itu terdapat kawasan hutan mangrove alami yang termasuk di dalam kawasan Taman Nasional Kutai (TNK) dengan diisi pula satwa di dalamnya (Burung elang bondol, kuntul perak, raja udang, kera ekor panjang, bekantan, ular dsb)

Hutan Mangrove yang dikonservasi berada di kawasan Taman Nasional Kutai dan dikonservasi berdasarkan Perda Kota Bontang Nomor 7 Tahun 2004, serta kawasan terumbu karang dikonservasi berdasarkan Perda RTRW Nomor 11 Tahun 2011. Disamping itu,terrdapat pula kawasan mangrove (Tanjung mamat) yang di konservasi masyarakat, sebagai buffer pemukiman nelayan dari hempasan angin dan gelombang.

8) Keberlanjutan

Terdapat kegiatan pelestarian lingkungan secara berkelanjutan dengan program adopsi mangrove dan terumbu karang. Selain itu masyarakat juga diajak untuk ikut serta dalam berbagai kegiatan ekowisata untuk menunjang perekonomian mereka seperti membuat berbagai olahan hasil laut yang dijadikan sebagai souvenir bahkan diekspor hingga keluar negeri.

Adanya kampung laut tentunya ikut menyumbang limbah rumah tangga tiap harinya. Untuk pengelolaan sanitasi dan limbah bagi pemukiman atas laut telah dikelola secara terpadu melalui Instalasi Pengolahan Air Limbah (IPAL) terpadu, dengan system Aerob dan Anaerob.

Berikut ini dokumentasi hasil observasi di wilayah penelitian :

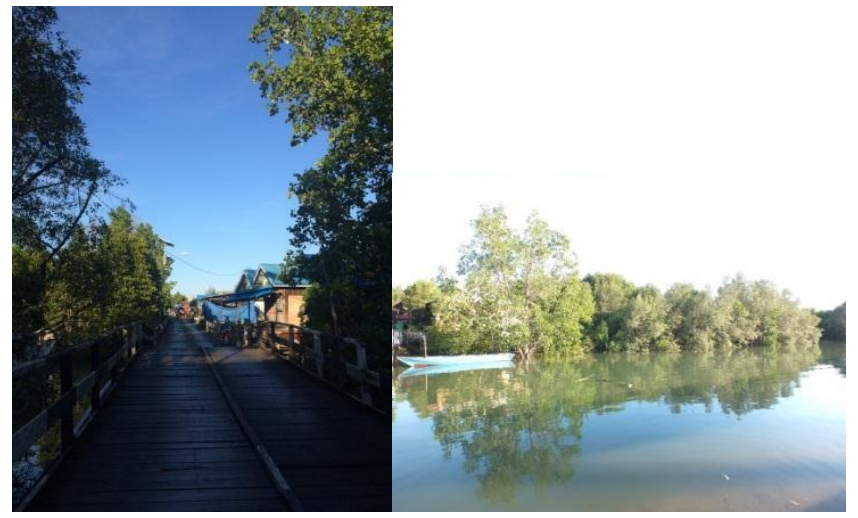

Gambar 6 Potret lingkungan alamiah yang didominasi oleh konservasi mangrove

Sumber : Survey Primer, 2016

\section{9) Kualitas SDM Masyarakat Lokal}

Pada kawasan wisata Kampung Laut Bontang Kuala berdasarkan hasil pengamatan diketahui bahwa kualitas SDMnya cukup baik. Pemerintah dan pihak swasta yakni PT. Badak LNG berkerja sama melakukan pembinaan terhadap masyarakat pesisir dengan berbagai kegiatan yang dapat meningkatkan kualitas masyarakat di sini seperti penanaman bibit terumbu karang bersama dengan MASKAPEI (Kelompok Masyarakat Kreatif Pesisir) sebagai upaya pelestarian 
lingkungan kawasan tersebut. Berikut ini dokumentasi hasil observasi di wilayah penelitian :

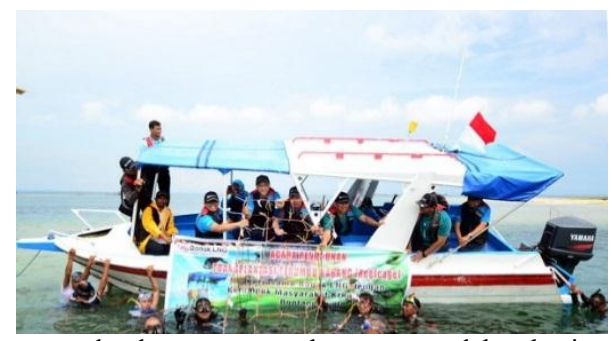

Gambar 7 Potret pemberdayaan masyarakat setempat dalam kegiatan penanaman mangrove

Sumber : Survey Primer, 2016

\section{0) Bernilai Edukasi}

Pada kawasan wisata Kampung Laut Bontang Kuala berdasarkan hasil pengamatan diketahui bahwa terdapat instalasi pengelolaan limbah yang ada di kawasan wisata ini. Di mana biasanya dijadikan sarana belajar untuk anak-anak sekolah di Kota Bontang terkait dengan pengelolaan limbah rumah tangga. Selain itu masyarakat juga mendapat pengalaman terkait dengan knservasi mangrove, melihat bagaimana aktivitas masyarakat setempat dan serta perayaan lain seperti pesta laut yan diakan setiap akhir tahun.

11) Pemberdayaan Masyarakat Lokal

Pada kawasan wisata Kampung Laut Bontang Kuala berdasarkan hasil pengamatan diketahui bahwa masyarakat mulai diajak dan diberdayakan dalam upaya memelihara lingkungan alamiah disekitar kawasan wisata Kampung Laut Bontang Kuala. Pemerintah bekerja sama dengan Community Development PT. Badak LNG ikut serta dalam penanaman kembali terumbu karang disekitar perairan di kawasan wisata Kampung Laut Bontang Kuala.

12) Manajemen Pengelolaan

Pada kawasan wisata Kampung Laut Bontang Kuala berdasarkan hasil pengamatan diketahui bahwa pengelolaan sendiri belum sepenuhnya berjalan dengan baik. Masih belum ada sistem yang jelas antara pemerintah dengan masyarakat. Sehingga masih perlu banyak pembenahan dari segi manajemen pengelolaan.

\section{3) Promosi}

Promosi yang dilakukan saat ini masih melalui media sosial seperti pamflet, iklan di koran maupun Facebook. Sedangkan saat ini websitenya sedang dibangun oleh pemuda karang taruna. Ada juga promosi yang dilakukan dinas pariwisata yang bekerja sama dengan kominitas backpaker yang mengadakan acara games berkeliling kawasan wisata kampung Laut Bontang Kuala kepada para pesertanya yang masing-masing dari mereka harus menyelesaikan beberapa kegiatan yang di kawasan wisata tersebut.

\section{4) Tingkat Ekonomi Lokal}

Ekonomi menjadi hal yang perlu diperhitungkan Tingkat perekonomian masyarakat setempat kawasan wisata ini cukup tinggi. Terlihat dari adanya KUBE ( Kelompok Usaha Bersama ) di kawasan wisata ini sebanyak 3 buah. Selain itu ada usaha lainnya seperti usaha pembuatan dan pengemasan olahan hasi laut ( ikan asin, agar-agar rumput laut, kerupuk ikan, teripang, dan olahan laut lainnya ), usaha kuliner ( restoran, café, dll ), budidaya keremba, usaha pembuatan perahu dan program bank sampah [10]

15) Tingkat Pendapatan Masyarakat Setempat

Pada kawasan wisata Kampung Laut Bontang Kuala berdasarkan hasil pengamatan diketahui bahwa sejauh ini pendapatan masyarakat yang tinggal di kawasan perkampungan atas laut ini beragam tergantung dari pekerjaan masing. Namun sebagian besar pendapatan masyarakat bersal dari sektor usaha olahan hasi laut [11]

Pelaku Ecowisata, saling berkaitan yakni dengan melibatkan Karang Taruna Bontang Kuala dan Pemuda Masyarakat Kreatif pesisir (Maskapei), untuk mengelola pusat informasi, dan menjadi guide, pengelola rumah makan untuk pengelolaan Ecowisata, saat ini setiap minggu telah melayani tamu sebanyak 150 s/d 200 orang. Dengan penghasilan antara 4000.000,- s/d 5000.000 ,- per minggu yang dikelola oleh Karang Taruna.

Potensi yang dimiliki kawasan wisata Kampung laut Bontang Kuala diantaranya yakni bentang alam dan panorama alam yang baik, potensi pesisir dan bawah lautnya sangat baik seperti adanya beragam terumbu karang, adanya konservasi mangrove dengan berbagai satwa langka yang ada di dalamnya. Ditambah dengan hasil laut yang baik seperti rumput laut, berbagai jenis ikan laut, teripang, dan lainnya yang dapat diolah kembali.

\section{6) Peluang Kerja Masyarakat Setempat}

Berdasarkan hasil pengamatan di wilayah penelitian diketahui bahwa dominasi pekerjaan masyarakat di sini adalah nelayan. Namun peluang kerja di bidang lainnya. Pada tahun 2015 terlihat bahwa banyak masyarakat yang memiliki beragam profesi selain sebagai nelayan. Selain itu, jumlah masyarakat usia produktif yang bekerja jumlahnya lebih banyak daripada masyarakat usia produktif yang tidak bekerja [12]

Dari tabel hasil analisis diatas bisa diketahui bahwa secara keseluruhan komponenen pariwisata dan ekowisata yang ada di kawasan wisata Kampung Laut Bontang Kuala sebagian besar sudah sesuai dengan komponen pariwisata dan ekowisata yang didapatkan dari hasil sintesa tinjauan pustaka yang ada terkait dengan komponen pariwisata dan ekowisata. Namun ada satu komponen pariwisata yang belum tersedia pada kawasan wisata, yakni belum adanya trayek dan angkutan umum yang menuju kawasan wisata tersebut. Sejauh ini pengunjung yang datang ke kawasan wisata ini menggunakan kendaraan pribadi mereka masing-masing. Tidak adanya trayek angkutan umum menuju kawasan ini sedikit menyusahkan para pengunjung yang tidak memiliki kendaraan pribadi. Sedangkan dari segi pemenuhan sarana dan prasarana wisata lainnya sudah cukup baik. Sedangkan dari segi pemenuhan komponen ekowisata, sebagian besar sudah sesuai dengan komponen ekowisata yang seharusnya dimiliki sebuah kawasan wisata yang akan dikembangkan sebagai kawasan ekowisata.

Berdasarkan hasil pengamatan komponen pariwisata dan ekowisata yang ada di kawasan wisata Kampung Laut Bontang Kuala tersebut dapat maka dapat dilihat bagaimana karakteristik pariwisata di kawasan wisata Kampung Laut Bontang Kuala. Dari hasil observasi diatas dapat dilihat mana saja komponen ekowisata yang terdapat di Kawasan wisata Kampung Laut Bontang Kuala merupakan kawasan wisata alam yang memiliki daya tarik wisata alam bahari adalah sebagai berikut :

A. Daya Tarik Alam dan Budaya (Alamiah, Konservasi) 
Pada kawasan ini memberikan daya tarik alamnya berupa wisata bahari, wisata edukasi konservasi mangrove dan wisata budaya. Menyuguhkan panorama keindahan perkampungan nelayan dan pesona lautnya. Selain itu terdapat pula kawasan konservasi mangrove yang cukup luas $(127 \mathrm{Ha})$ dan juga kawasan konservasi terumbu karang. Berdasarkan teori terkait ekowisata yang telah dijelaskan sebelumnya, bahwa kawasan ekowisata merupakan kawasan yang mempunyai kawasan konservasi dan dapat memberikan nilai edukasi maupun ekonomi kepada masyarakat sekitar kawasan wisata tersebut. Kondisi tersebut sudah terlihat di kawasan wisata Kampung Laut Bontang Kuala. Didukung pula dengan beberapa kegiatan karang taruna setempat yang bekerja sama dengan pihak CSR Pt. Badak LNG melakukan berbagai kegiatan berbasis ekowisata.

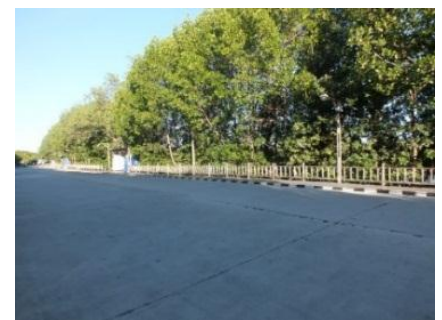

Gambar 8. Salah satu daya tarik alam yang ada di Kawasan Wisata Kampung Laut Bontang Kuala

Sumber : Survey Primer, 2016

B. Sosial Budaya Masyarakat Setempat Kawasan Wisata Kampung Laut Bontang Kuala

Mencakup semua kawasan perkampungan nelayan yang ada di Kawasan Wisata Kampung Laut Bontang Kuala. Rumah rumah nelayan yang dengan desain yang unik terbuat dari kayu menjadi daya tarik tersendiri bagi para wisatawan. Selain bangunan perkampungan yang menjadi daya tarik bagi wisatawan, kehidupan sehari-hari masyarakat lokal setempat juga bisa menjadi daya tarik wisatawan yang tidak didapatkan pada kawasan wisata lainnya.

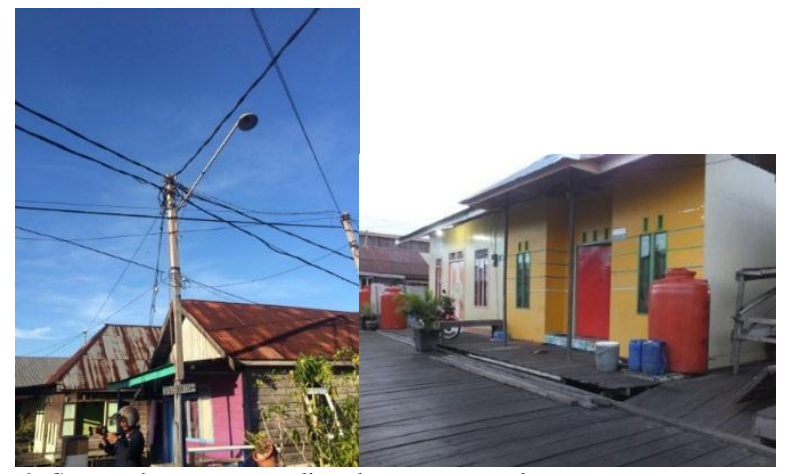

Gambar 9. Sarana dan prasarana di perkampungan nelayan Sumber : Survey Primer, 2016

C. Kegiatan Ekonomi Masyarakat Setempat (Olahan Hasil Laut)

Terlihat dari adanya KUBE ( Kelompok Usaha Bersama ) di kawasan wisata ini sebanyak 3 buah yang bergerak dibidang pengolahan hasil laut dan pembutan perahu. Selain itu ada usaha lainnya seperti usaha pembuatan dan pengemasan olahan hasi laut ( ikan asin, agar-agar rumput laut, kerupuk ikan, teripang, dan olahan laut lainnya), usaha kuliner ( restoran, café, dll ), budidaya keramba, usaha pembuatan perahu dan program bank sampah.

\section{KESIMPULAN}

Secara keseluruhan komponenen pariwisata dan komponen ekowisata yang ada di kawasan wisata Kampung Laut Bontang Kuala sebagian besar sudah lengkap kecuali belum adanya trayek dan angkutan umum menuju kawasan wisata tersebut. Dari segi pemenuhan sarana dan prasarana wisata lainnya sudah cukup baik. Hal tersebut jika dilihat dari segi pemenuhan komponen pariwisata. Sedangkan dari segi pemenuhan komponen ekowisata, sebagian besar sudah sesuai dengan komponen ekowisata yang seharusnya dimiliki sebuah kawasan wisata yang akan dikembangkan sebagai kawasan ekowisata. Dan dari kelengkapan komponen tersebut dapat dilihat bagaimana karakteristik wisata di wilayah penelitian. Pada kawasan penelitian didominasi dengan adanya daya tarik alam dan budaya berupa wisata bahari; mangrove; dan wisata budaya, kehidupan sosial budaya masyarakat kampung laut dan kondisi ekonomi di kawasan wisata Kampung Laut Bontang Kuala. Oleh karena itu kawasan ini cocok untuk dikembangkan sebagai kawasan ekowisata.

\section{DAFTAR PUSTAKA}

[1] Dokumen Data Pariwisata Kota Bontang Tahun 2014

[2] Idajati, Hertiari. 2013.Cultural And Tourism Planning As Tool For City Revitalization.. Surabaya : Urban and Regional Planning ITS, 2013.

[3] www.kaltimprov.go.id (diakses pada 11 Oktober 2015)

[4] Profil Kota Bontang Tahun 2014

[5] Rencana Pembangunan Jangka Menengah Daerah Kota Bontang Tahun $2011-2016$

[6] Dokumen Data Pariwisata Kota Bontang Tahun 2014

[7] www.pariwisatakaltim.com (diakses pada 13 Oktober 2015 )

[8] Idajati, Hertiari. 2015. Laporan Akhir Peneliti Pemula Pendekatan Participatory Planning dalam Optimalisasi Pengembangan Ekowisata Mangrove di Surabaya. Surabaya : LPPM ITS, 2015.

[9] Imam Asy'ari, Sapari. 1993. Sosiologi Kota dan Desa. Surabaya : Usaha Nasional Surabaya

[10] Buku Monografi Kelurahan Bontang Kuala Tahun 2014/2015

[11] Buku Monografi Kelurahan Bontang Kuala Tahun 2014/2015

[12] Kecamatan Bontang Utara Dalam Angka 2014 